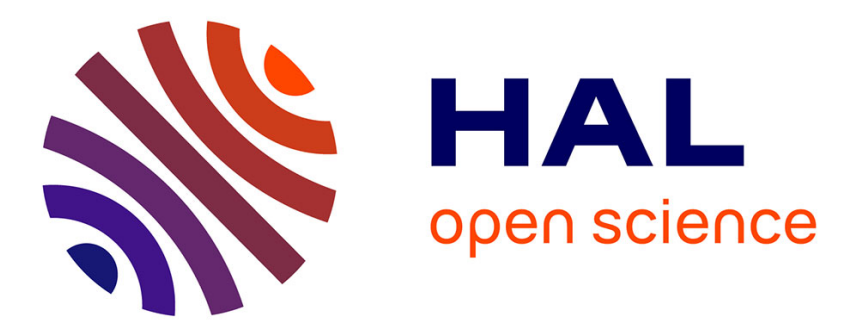

\title{
Physicochemical and Spectroscopic Characterization of p-Chlorobenzaldehyde: An Impact of Biofield Energy Treatment
}

\author{
Mahendra Kumar Trivedi, Alice Branton, Dahryn Trivedi, Gopal Nayak, \\ Khemraj Bairwa, Snehasis Jana
}

\section{To cite this version:}

Mahendra Kumar Trivedi, Alice Branton, Dahryn Trivedi, Gopal Nayak, Khemraj Bairwa, et al.. Physicochemical and Spectroscopic Characterization of p-Chlorobenzaldehyde: An Impact of Biofield Energy Treatment. Insights in Analytical Electrochemistry, 2015, 1 (1). hal-01461280

\author{
HAL Id: hal-01461280 \\ https://hal.science/hal-01461280
}

Submitted on 8 Feb 2017

HAL is a multi-disciplinary open access archive for the deposit and dissemination of scientific research documents, whether they are published or not. The documents may come from teaching and research institutions in France or abroad, or from public or private research centers.
L'archive ouverte pluridisciplinaire HAL, est destinée au dépôt et à la diffusion de documents scientifiques de niveau recherche, publiés ou non, émanant des établissements d'enseignement et de recherche français ou étrangers, des laboratoires publics ou privés. 


\section{Physicochemical and Spectroscopic Characterization of $\boldsymbol{p}$-Chlorobenzaldehyde: An Impact of Biofield Energy Treatment}

\section{Abstract}

$p$-Chlorobenzaldehyde ( $p$-CBA) is used as an important chemical intermediate for the preparation of pharmaceuticals, agricultural chemicals, dyestuffs, optical brighteners, and metal finishing products. The study aimed to evaluate the effect of biofield energy treatment on the physicochemical and spectroscopic properties of $p$-CBA. The study was accomplished in two groups i.e. control and treated. The control group was remained as untreated, while the treated group was subjected to Mr. Trivedi's biofield energy treatment. Finally, both the samples (control and treated) were evaluated using various analytical techniques. The surface area analysis showed a substantial increase in the surface area by $23.06 \%$ after biofield treatment with respect to the control sample. The XRD analysis showed the crystalline nature of both control and treated samples. The X-ray diffractogram showed the significant alteration in the peak intensity in treated sample as compared to the control. The XRD analysis showed the slight increase (2.31\%) in the crystallite size of treated sample as compared to the control. The TGA analysis exhibited the decrease $(10 \%)$ in onset temperature of thermal degradation form $140^{\circ} \mathrm{C}$ (control) to $126^{\circ} \mathrm{C}$ in treated sample. The $\mathrm{T}_{\max }$ (maximum thermal degradation temperature) was slightly decreased $(2.14 \%)$ from $157.09^{\circ} \mathrm{C}$ (control) to $153.73^{\circ} \mathrm{C}$ in treated sample of $p$-CBA. This decrease in $T_{\max }$ was possibly due to early phase of vaporization in treated sample as compared to the control. The FT-IR spectrum of treated $p$-CBA showed the increase in wavenumber of $\mathrm{C}=\mathrm{C}$ stretching as compared to the control. The UV spectroscopic study showed the similar pattern of wavelength in control and treated samples.

Altogether, the surface area, XRD, TGA-DTG and FT-IR analysis suggest that Mr. Trivedi's biofield energy treatment has the impact to alter the physicochemical properties of $p$-CBA. This treated $p$-CBA could be utilized as a better chemical intermediate than the control $p$-CBA for the synthesis of pharmaceutical drugs and organic chemicals.

Keywords: Biofield energy treatment; $p$-Chlorobenzaldehyde; Surface area; X-Ray diffraction; Fourier transform infrared spectroscopy; UV-Vis spectroscopy.

Abbreviations: NCCAM: National Center for Complementary and Alternative Medicine; NIH: National Institute of Health; XRD: X-ray diffraction; TGA: Thermogravimetric analysis; DTG: Derivative Thermogravimetry
Mahendra Kumar Trivedi', Alice Branton ${ }^{1}$, Dahryn Trivedi ${ }^{1}$, Gopal Nayak ${ }^{1}$, Khemraj Bairwa² and Snehasis Jana²

1 Trivedi Global Inc., 10624 S Eastern Avenue Suite A-969, Henderson, NV 89052, USA

2 Trivedi Science Research Laboratory Pvt. Ltd., Hall-A, Chinar Mega Mall, Chinar Fortune City, Hoshangabad Rd., Bhopal, Madhya Pradesh, India

Corresponding author: Snehasis Jana

¡ publication@trivedieffect.com

Trivedi Science Research Laboratory Pvt. Ltd., Hall-A, Chinar Mega Mall, Chinar Fortune City, Hoshangabad Rd., Bhopal-462 026, Madhya Pradesh, India.

Tel: +91-755-6660006

Citation: Trivedi MK, Branton A, Trivedi D, et al. Physicochemical and Spectroscopic Characterization of p-Chlorobenzaldehyde: An Impact of Biofield Energy Treatment. Insights Anal Electrochem. 2015, 1:1

Received: September 23, 2015; Accepted: October 17, 2015; Published: October 29, 2015

\section{Introduction}

$p$-Chlorobenzaldehyde ( $p$-CBA) is an organic compound comprising of benzene ring with formyl and chlorine substituents at 1 and 4 positions, respectively. The $p$-CBA is used as an important reaction intermediate for the manufacturing of several pharmaceutical drugs and agricultural chemicals [1]. It is used in the production of triphenyl methane and related dyes. It is also 
used for optical brighteners and metal finishing products [1,2] The $p$-CBA is commercially produced by side-chain chlorination of $p$-CBA followed by acid hydrolysis [3]. The $p$-CBA along with $p$-chloroaniline is used for the synthesis of Schiff base. The Schiff bases are versatile imine $(\mathrm{C}=\mathrm{N})$ containing compounds having broad spectrum of biological activities [4]. The incorporation of metals in Schiff base in the form of metal complexes exhibited some degree of biological activities like antifungal [5], antibacterial [6], anticancer [7], and anti-inflammatory activity [8]. As $p$-CBA used as an important reaction intermediate, its rate of reaction plays a crucial role. The literature suggests that any alteration in crystallite size and surface area can affect the kinetics of reaction [9]. Moreover, the thermal properties i.e. vaporization temperature, decomposition temperature of chemical compound also affect the reaction kinetics [10]. Therefore, considering the importance of $p$-CBA, it is important to discover an alternate and safe approach, which can improve the overall physicochemical properties of compound. Recently, biofield energy treatment has been reported to alter the physicochemical as well as spectral properties of various organic compounds and pharmaceutical drugs [11-13].

The National Institute of Health/National Center for Complementary and Alternative Medicine (NIH/NCCAM) conceived the healing energy (putative energy fields) treatment under the subcategory of energy therapies [14]. It is reported that human body is permeated and surrounded with the bioenergetic field (subtle energy field) [15]. The health of living organism depends on the balance of this bioenergetics field. In the diseased situation, this bioenergetics field gets depleted [16]. The experts of energy medicine manipulate and balance this bioenergetics field via harnessing the energy from the Universe [17]. Thus, the human (expert of energy medicine) has the ability to harness the energy from the Universe and transfer it to any living or nonliving object to balance or re-pattern the electromagnetic energy field [18]. The objects always receive this energy and respond in the useful way [19]. The biofield energy therapy is being practiced in the form of healing therapy or therapeutic touch throughout the world and especially in the western countries $[20,21]$. It is estimated that about $36 \%$ of Americans regularly uses some form of Complementary and Alternative Medicine (CAM) [22]. The biofield energy treatment is effectively used to stimulate the overall health of human being by reducing the pain and anxiety $[23,24]$

Mr. Trivedi is well known for his unique biofield energy treatment (The Trivedi Effect ${ }^{\circ}$ ) that has been evaluated in numerous arenas like agricultural research [25], biotechnology research [26], microbiology research $[27,28]$, pharmaceutical sciences $[13,19]$, and materials science $[29,30]$.

Hence, based on the prominent impact of biofield energy treatment and significance of $p$-CBA as a chemical intermediate, the present study was aimed to evaluate the effect of $\mathrm{Mr}$. Trivedi's biofield energy treatment on the physicochemical and spectroscopic properties of $p$-CBA. The analysis was done using surface area analyzer, X-ray diffractometry (XRD), thermogravimetric analysis-derivative thermogravimetry (TGADTG), Fourier transform infrared (FT-IR) spectroscopy, and UV-Vis spectrometry.

\section{Materials and Methods}

\section{Study design}

The $p$-chlorobenzaldehyde ( $p$-CBA) was purchased from Loba Chemie Pvt. Ltd., India. The $p$-CBA was divided into two groups i.e. control and treated. The control sample was kept without treatment, while the treated sample in sealed pack was handed over to Mr. Trivedi to render the biofield energy treatment under laboratory conditions. Mr. Trivedi provided the biofield energy treatment to the treated group via his unique energy transmission process without touching the sample [13]. Afterward, both the control and treated samples were analyzed with respect to physicochemical and spectroscopic properties using various techniques like surface area analyzer, XRD, TGA-DTG, FT-IR and UV-vis spectroscopy.

\section{Surface area analysis}

The surface area of control and treated $p$-CBA was analyzed using the Brunauer-Emmett-Teller (BET) surface area analyzer (Smart SORB 90) based on the ASTM D 5604 method. The range of the instrument was $0.2 \mathrm{~m}^{2} / \mathrm{g}$ to $1000 \mathrm{~m}^{2} / \mathrm{g}$. The percent change in surface area was calculated with the help of following equation:

$\%$ change in surface area $=\frac{\left[\mathrm{S}_{\text {Treated }}-\mathrm{S}_{\text {Control }}\right]}{\mathrm{S}_{\text {Control }}} \times 100$

Here, $\mathrm{S}_{\text {control }}$ is the surface area of the control sample and $\mathrm{S}_{\text {Treated }}$ is the surface area of treated sample.

\section{XRD study}

The XRD analysis of $p$-CBA (control and treated) samples was done on Phillips (Holland PW 1710) X-ray diffractometer with copper anode and nickel filter. The wavelength of XRD system was set to $1.54056 \AA$. The percent change in average crystallite size $(G)$ was calculated using following equation:

$\mathrm{G}=\left[\left(\mathrm{G}_{\mathrm{t}}-\mathrm{G}_{\mathrm{c}}\right) / \mathrm{G}_{\mathrm{c}}\right] \times 100$

Here, $G_{c}$ and $G_{t}$ are average crystallite size of control and treated powder samples, respectively.

\section{TGA-DTG analysis}

The TGA-DTG analysis was carried out on Mettler Toledo simultaneous TGA-DTG analyzer. The analytes were heated up to $400^{\circ} \mathrm{C}$ from room temperature at the heating rate of $5^{\circ} \mathrm{C} /$ min under air atmosphere. The onset temperature of thermal degradation and $T_{\text {max }}$ (temperature at which maximum weight loss occur) in samples were obtained from TGA-DTG thermogram.

\section{Spectroscopic studies}

The treated sample of $p$-CBA was divided into two groups i.e. T1 and T2 for the FT-IR and UV-vis spectroscopy. The spectral data of treated samples were compared with the respective spectral data of control sample.

\section{FT-IR spectroscopic characterization}

The FT-IR spectroscopy was done to determine the effect of biofield energy treatment on dipole moment, force constant, and bond strength in chemical structure [31]. The samples for FT-IR 
analysis were prepared by crushing with spectroscopic grade $\mathrm{KBr}$ into fine powder. Subsequently, the mixture was pressed into pellets. The spectra were obtained from Shimadzu's Fourier transform infrared spectrometer (Japan) with the frequency range of $500-4000 \mathrm{~cm}^{-1}$.

\section{UV-Vis spectroscopic analysis}

The UV spectra of control and treated samples of $p$-CBA were obtained from Shimadzu UV spectrometer (2400 PC) with quartz cell of $1 \mathrm{~cm}$ and a slit width of $2.0 \mathrm{~nm}$. The analysis was done at the wavelength range of $200-400 \mathrm{~nm}$.

\section{Results and Discussion}

\section{Surface area analysis}

The surface area of control and treated $p$-CBA are shown in Figure 1. The surface area of control and treated sample were found as $0.2498 \mathrm{~m}^{2} / \mathrm{g}$ and $0.3074 \mathrm{~m}^{2} / \mathrm{g}$, respectively. The result showed an increase in surface area by $23.06 \%$ in the treated sample with respect to the control sample. It is well known that surface area is inversely proportional to the particle size [32]. Based on this, it is presumed that biofield energy induced the milling process, which leads to decrease the particle size of treated sample. As a result, the surface area of treated sample was increased significantly.

\section{XRD analysis}

The XRD diffractograms of $p$-CBA (control and treated) samples are shown in Figure 2. The XRD diffractograms of both samples showed the sharp and intense peaks that suggest the crystalline nature of control and treated samples. The XRD diffractogram of control sample showed the peaks at $2 \theta$ equal to $13.6^{\circ}, 16.8^{\circ}$, $17.09^{\circ}, 18.85^{\circ}, 19.06^{\circ}, 21.48^{\circ}, 26.86^{\circ}, 27.45^{\circ}, 41.01^{\circ}$, and $42.91^{\circ}$. Similarly, the XRD diffractogram of treated $p$-CBA exhibited the XRD peaks at $2 \theta$ equal to $13.73^{\circ}, 14.98^{\circ}, 16.71^{\circ}, 19.19^{\circ}, 27.26^{\circ}$, $29.38^{\circ}, 30.61^{\circ}, 40.81^{\circ}, 42.35^{\circ}$, and $47.77^{\circ}$. The Figure 2 showed the significant alteration in the intensity of XRD peaks intensity after biofield treatment as compared to the control sample. The most intense peak in control sample was observed at $19.06^{\circ}$; while in treated sample the most intense peak was observed at $29.38^{\circ}$. The literature suggests that alteration in crystal morphology may lead to alteration in relative intensities of the

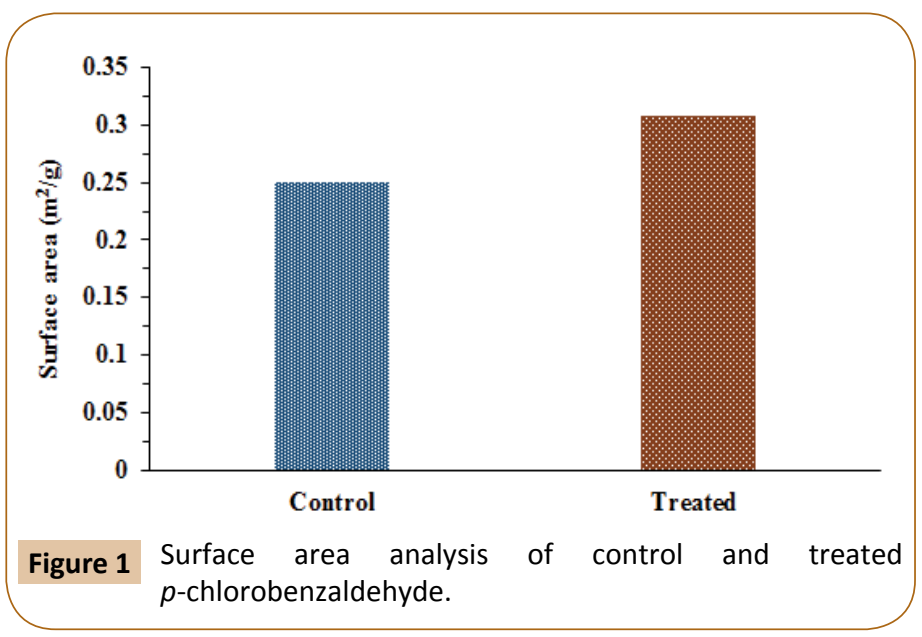

peaks [33]. Additionally, it is reported that internal strain can also change the $2 \theta$ values [34]. Based on this, it is hypothesized that biofield energy treatment was induced an internal strain in the treated sample that might be responsible for the alteration in its $2 \theta$ values with respect to the control sample.

The average crystallite size of the control sample was calculated as $154.52 \mathrm{~nm}$, while the crystallite size of treated sample was calculated as $158.09 \mathrm{~nm}$. The result depicted a slight increase $(2.31 \%)$ in the crystallite size of treated sample with respect to the control (Figure 3). It is previously reported that increase in annealing temperature expressively affects the crystallite size of the compounds. The increase in temperature might lead to decrease in dislocation density and increase in the number of unit cell; these finally increases the average crystallite size of sample $[35,36]$. Based on this, it is assumed that biofield treatment might provide some thermal energy to $p$-CBA molecules. Consequently, the dislocation density might be reduced and thus the number of unit cells and average crystallite size were increased in the treated sample.

\section{TGA-DTG analysis}

The TGA-DTG thermogram of $p$-CBA samples (control and treated) are shown in Figure $\mathbf{4}$ and data are presented in (Table 1). The TGA thermogram of control sample showed an initiation (on-set) of thermal degradation at $140^{\circ} \mathrm{C}$, which was ended (end-set) at
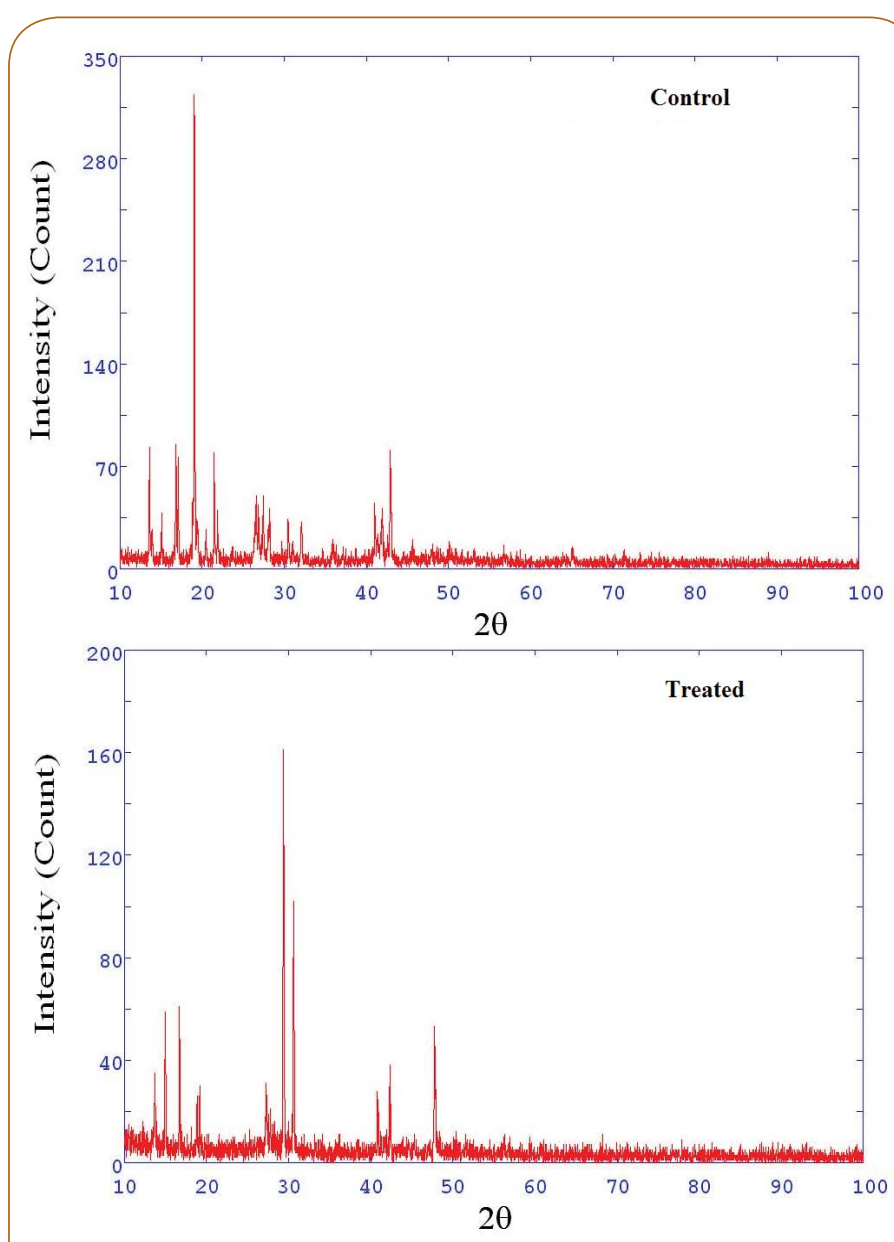

Figure 2 XRD diffractogram of $p$-chlorobenzaldehyde. 

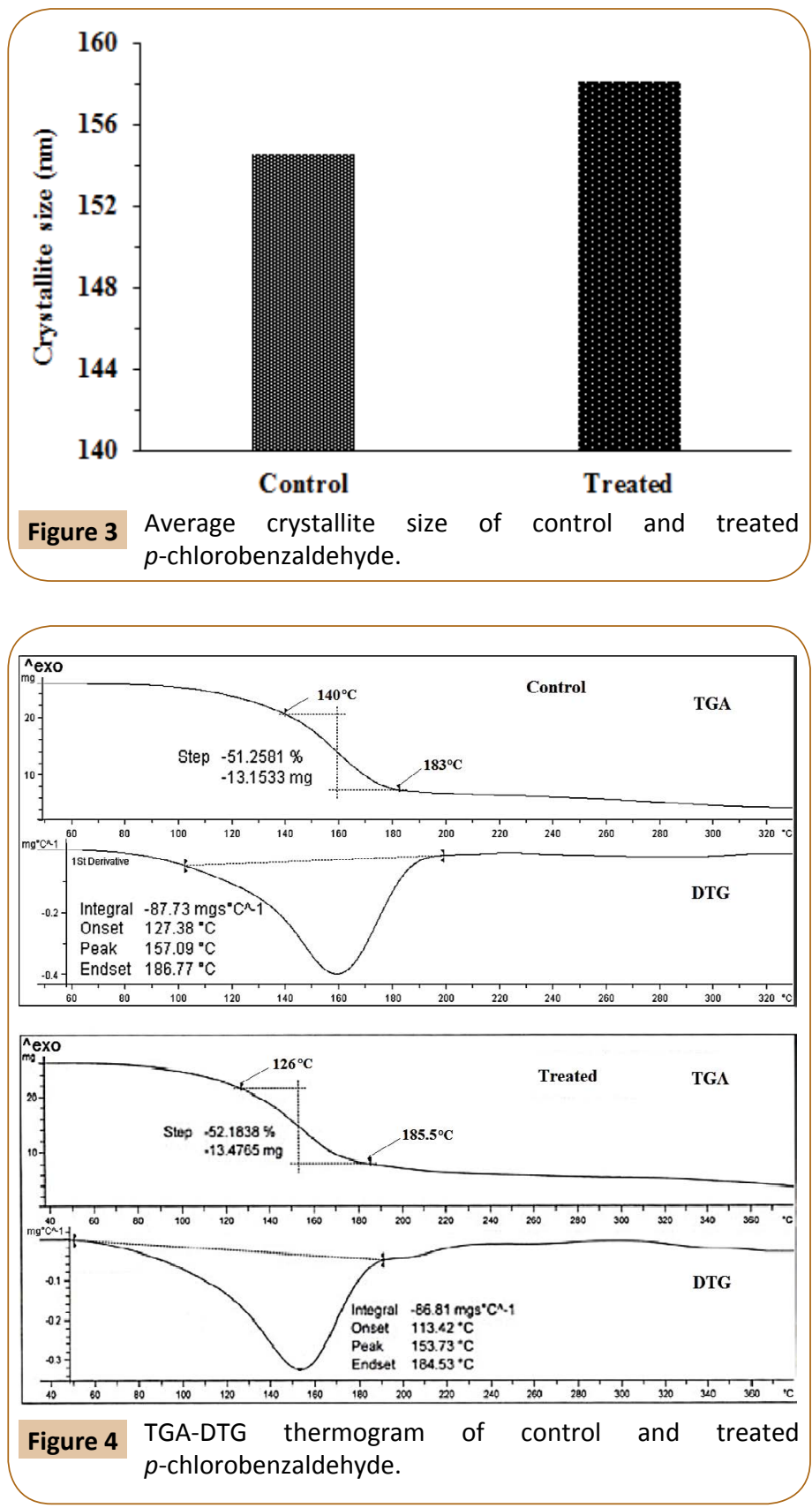

Table 1 Thermal analysis of control and treated samples of $p$-chlorobenzaldehyde. $\mathrm{T}_{\max }$ : Temperature at maximum weight loss occurs.

\begin{tabular}{|ccc|}
\hline Parameter & Control & Treated \\
\hline Onset temperature $\left({ }^{\circ} \mathrm{C}\right)$ & 140.00 & 126.00 \\
\hline End-set temperature $\left({ }^{\circ} \mathrm{C}\right)$ & 183.00 & 185.50 \\
\hline $\mathrm{T}_{\max }\left({ }^{\circ} \mathrm{C}\right)$ & 157.09 & 153.73 \\
\hline
\end{tabular}

$183^{\circ} \mathrm{C}$. Similarly, the TGA thermogram of the treated sample exhibited the on-set temperature at $126^{\circ} \mathrm{C}$ that was terminated (end-set) at $185.5^{\circ} \mathrm{C}$. The result showed about $10 \%$ decrease in the onset temperature in biofield energy treated sample as compared to the control. The TGA-DTG study showed the decrease in thermal stability of treated sample with respect to the control that could be correlated to increase in the chemical reactivity of $p$-CBA. Moreover, the percentage weight loss during the thermal decomposition was found as $51.25 \%$ in the control, while $52.18 \%$ in the treated sample. The result showed a mere increase in percent weight loss during thermal decomposition of treated sample with respect to the control. Moreover, the DTG thermogram exhibited the $T_{\max }$ (temperature at which the sample lost its maximum weight) at $157.09^{\circ} \mathrm{C}$ in the control sample and at $153.73^{\circ} \mathrm{C}$ in the treated sample. The result showed about $2.14 \%$ decrease in $\mathrm{T}_{\max }$ of treated sample as compared to the control. This might occur due to the changes in internal energy via biofield energy treatment, which may cause to early phase of evaporation in treated sample with respect to the control [37].

\section{FT-IR spectroscopic analysis}

FT-IR spectra of the control and treated $p$-CBA are shown in Figure 5. The $p-C B A$ molecule contains $=\mathrm{C}-\mathrm{H}, \mathrm{C}=\mathrm{C}, \mathrm{C}-\mathrm{C}, \mathrm{C}=\mathrm{O}$, $\mathrm{C}-\mathrm{Cl}$ groups of vibrations. The $=\mathrm{C}-\mathrm{H}$ (aromatic) stretching was attributed to peaks at $3088 \mathrm{~cm}^{-1}$ in control and treated (T1 and T2) samples. While, the aldehyde $\mathrm{C}-\mathrm{H}$ stretching was assigned to peak appeared at $2860 \mathrm{~cm}^{-1}$ in all the control and treated samples. The aldehyde $\mathrm{C}-\mathrm{H}$ asymmetrical bending was attributed to peak at $1485 \mathrm{~cm}^{-1}$ in all the three samples (control, T1 and T2). Moreover, the aldehyde $\mathrm{C}-\mathrm{H}$ symmetrical bending was attributed to peaks observed at $1386 \mathrm{~cm}^{-1}$ in control and T1 sample and 1384 $\mathrm{cm}^{-1}$ in $\mathrm{T} 2$ sample. The out of plane ring deformation was assigned

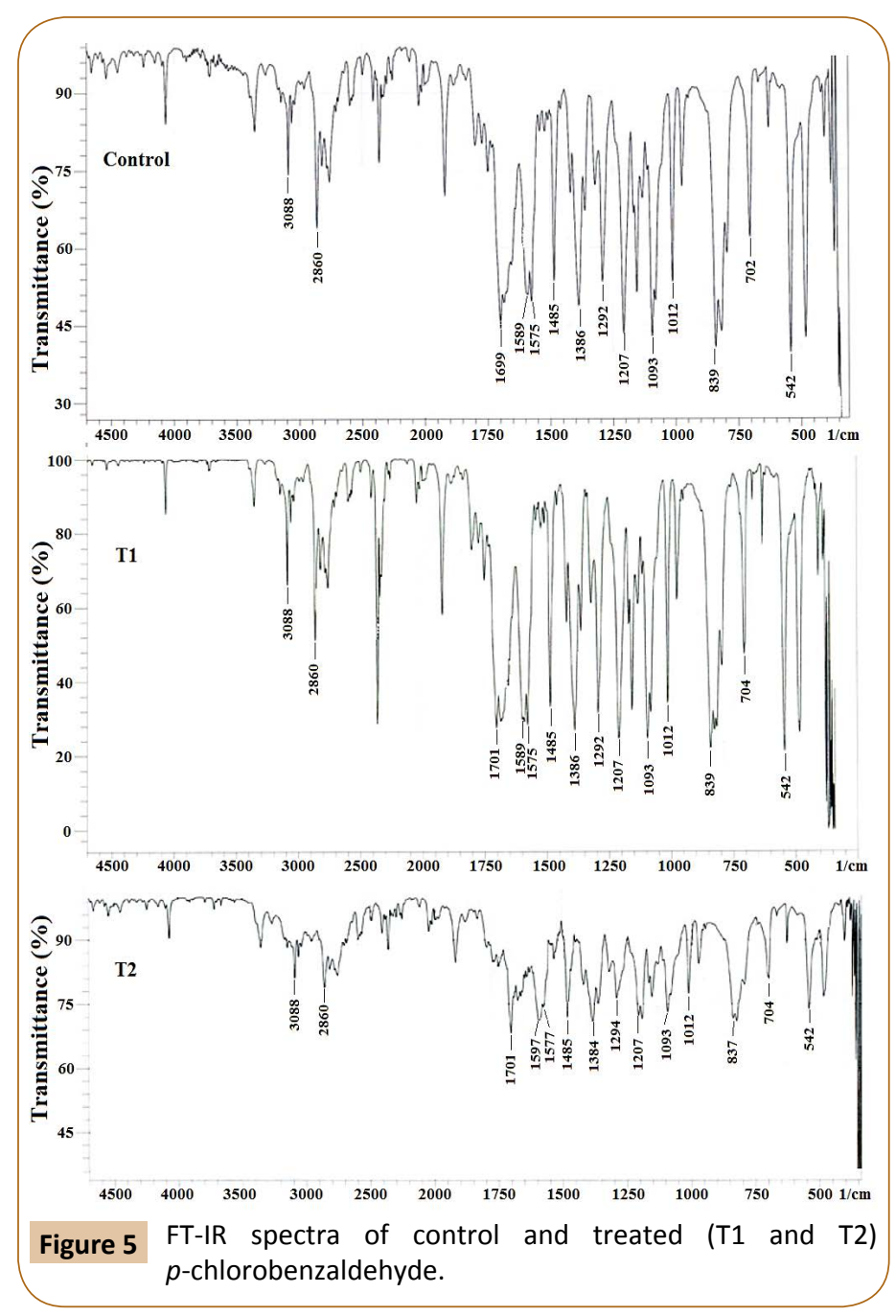


to peaks at $1093-1207 \mathrm{~cm}^{-1}$ region of spectra in all three samples; whereas, the in-plane deformation was assigned to peaks in the range of 702-839 $\mathrm{cm}^{-1}$ (control), 704-839 $\mathrm{cm}^{-1}$ (T1), and 704-837 $\mathrm{cm}^{-1}(\mathrm{~T} 2)$ sample.

The $\mathrm{C}=\mathrm{C}$ (aromatic) stretching was assigned to peaks appeared at $1575-1589 \mathrm{~cm}^{-1}$ in control and T1 samples, while it was appeared at $1577-1597 \mathrm{~cm}^{-1}$ in T2 sample. Similarly, the C-C stretching was assigned to peaks at $1292 \mathrm{~cm}^{-1}$ in control and T1 samples, while it was observed at $1294 \mathrm{~cm}^{-1}$ in $\mathrm{T} 2$ sample. The $\mathrm{C}=\mathrm{O}$ stretching peak was assigned to peaks at $1699 \mathrm{~cm}^{-1}$ in control sample and $1701 \mathrm{~cm}^{-1}$ in the treated samples. In addition, the $\mathrm{C}-\mathrm{O}$ and $\mathrm{C}-\mathrm{Cl}$ stretching were appeared at $1012 \mathrm{~cm}^{-1}$ and $542 \mathrm{~cm}^{-1}$, respectively in all the three samples (control, T1 and T2).

The result showed a slight increase in the frequency of $\mathrm{C}=\mathrm{C}$ stretching in $\mathrm{T} 2$ sample as compared to the control. This is might be due to increased bond strength of $\mathrm{C}=\mathrm{C}$ group in treated $p-\mathrm{CBA}$ molecules as compared to the control. The stretching frequency of any bond depends on the dipole moment $(\mu)$ and reduced mass $(m)[38,39]$. Therefore, it is presumed that biofield energy treatment might increase the dipole moment of $\mathrm{C}=\mathrm{C}$ bond as compared to the control sample. Except this, rest of the IR vibration peaks were appeared at the similar frequency region in all three samples.

\section{UV-Vis spectroscopy}

UV spectra of the control and treated $p$-CBA are shown in Figure 6. The UV spectrum of control sample showed the absorbance maxima $\left(\lambda_{\max }\right)$ at 206.6 and $254.4 \mathrm{~nm}$. Similarly, the UV spectra of treated sample showed the $\lambda_{\max }$ at 206.8 and $254.6 \mathrm{~nm}$ in T1 and 207.5 and $254.0 \mathrm{~nm}$ in T2 sample. The result showed the similar pattern of absorbance maxima in the control and treated samples.

The compound absorbs UV waves due to transition of electrons from highest occupied molecular orbital (HOMO) to highest unoccupied molecular orbital (LUMO). When the energy gap between HOMO and LUMO (also called as HOMO-LUMO gap) altered, the wavelength $\left(\lambda_{\max }\right)$ was also altered [31]. However, the UV study of $p$-CBA showed the similar pattern of absorbance maxima in both the control and treated samples. Therefore, it can be concluded that the biofield treatment did not distract the energy gap between HOMO-LUMO in treated sample, as compared to the control sample.

\section{Conclusions}

In conclusion, the present study showed the substantial increase in surface area of treated sample by $23.06 \%$ as compared to the control sample. The XRD study showed the crystalline nature of both control and treated sample. Moreover, the intensity of XRD peaks were also altered after biofield treatment as compared

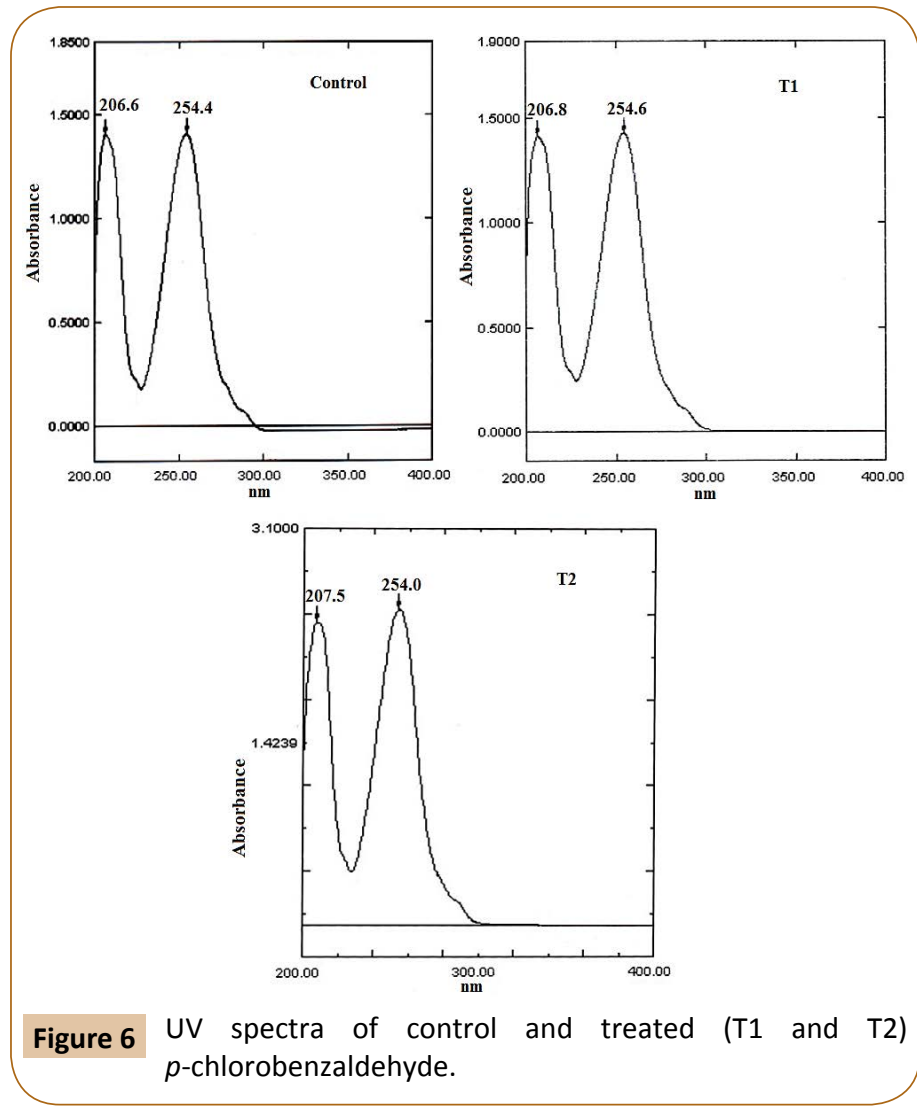

to the control. The TGA-DTG study showed the slight decrease $(10.0 \%)$ in onset temperature of thermal degradation with respect to the control. The decrease in thermal stability might be correlated to increase in chemical reactivity of $p$-CBA. The FT-IR data showed the upstream shifting of $C=C$ stretching frequencies with respect to the control. This might be due to the increase in force constant and bond strength of $\mathrm{C}=\mathrm{C}$ group in treated $p-\mathrm{CBA}$ molecule as compared to the control.

Overall, the present study concluded the substantial impact of Mr. Trivedi's biofield energy treatment on physicochemical and spectroscopic properties of $p$-CBA. Based on this, it is anticipated that Mr. Trivedi's unique biofield energy treatment can effectively transform the physicochemical properties of $p$-CBA into the more useful form so that it could be utilized as a better chemical intermediate for the synthesis of pharmaceutical drugs and organic chemicals.

\section{Acknowledgements}

The authors would like to acknowledge the Trivedi Science, Trivedi Master Wellness and Trivedi Testimonials for their sturdy support throughout the work. Authors would also like to thanks the whole team of MGV pharmacy college, Nashik to allowing the instrumental facility for this work. 


\section{References}

1 Keith LH, Walters DB (1991) The national toxicology program's chemical data compendium. (7th edn), Lewis publishers, INC., CRC Press, USA.

2 Sheldon RA, Bekkum HV (2001) Fine chemicals through heterogeneous catalysis, Wiley-VCH, Weinheim.

3 Deng Y-Q, Zhang T, Au CT, Yin SF (2014) Oxidation of $p$-chlorotoluene to $p$ - chlorobenzaldehyde over manganese-based octahedral molecular sieves of different morphologies. Catal Commun 43: 126-130.

4 Pattanaik S, Rout SS, Panda J, Sahu PK, Banerjee M (2011) Synthesis, characterisation and biological evaluation of bidentate ligands (reduced schiff's base) with metals of copper, nickel and zinc complexes. Rasayan J Chem 4: 136-141.

5 Singh NK, Kushawaha SK (2000) Synthesis, characterization and biological activity of the complex of manganese (II), iron (II), cobalt (II), nickel (II), copper (II), Zinc (II), and cadmium (II) with $n$-benzoyalfuranthiocarbohydrazide. Indian J Chem 39A: 1070-1073.

6 Henri LKW, Tagenine J, Gupta BM (2001) Synthetic and antibacterial studies of Schiff base complexes derived from 2,3-diaminopyridine and $o$-vanillin. Indian J Chem 40A: 999-1003.

7 El-Tabl MH, El-Saied FA, Ayad MI (2002) Manganese (II), iron (III), cobalt (II), nickel (II), copper (II), zinc (II), and uranyl (VI) complexes of $\mathrm{N}$-(4-formylantipyrine) benzothiazol-2-ylacetohydrazide. Synth React Inorg Metal Org Nan Metal Chem 32: 1245-1262.

8 Chohan ZH, Iqbal MS, Iqbal HS, Scozzafava A, Supuran CT (2002) Transition metal acetylsalicylates and their anti-inflammatory activity. J Enzyme Inhib Med Chem 17: 87-91.

9 Chaudhary AL, Sheppard DA, Paskevicius M, Pistidda C, Dornheim M (2015) Reaction kinetic behaviour with relation to crystallite/grain size dependency in the Mg-Si-H system. Acta Mater 95: 244-253.

10 Movaffaghi Z, Farsi M (2009) Biofield therapies: Biophysical basis and biological regulations. Complement Ther Clin Pract 15: 35-37.

11 Trivedi MK, Patil S, Shettigar H, Singh R, Jana S (2015) An impact of biofield treatment on spectroscopic characterization of pharmaceutical compounds. Mod Chem Appl 3: 159.

12 Trivedi MK, Patil S, Mishra RK, Jana S (2015) Structural and physical properties of biofield treated thymol and menthol. J Mol Pharm Org Process Res 3: 127.

13 Trivedi MK, Patil S, Shettigar H, Bairwa K, Jana S (2015) Spectroscopic characterization of chloramphenicol and tetracycline: An impact of biofield. Pharm Anal Acta 6: 395.

14 Koithan M (2009) Introducing complementary and alternative therapies. J Nurse Pract 5: 18-20.

15 Wilson CA (2011) Healing power beyond medicine. John Hunt Publishing Ltd., UK.

16 Warber SL, Cornelio D, Straughn J, Kile G (2004) Biofield energy healing from the inside. J Altern Complement Med 10: 1107-1113.

17 Stenger VJ (1999) Bioenergetic fields. Sci Rev Alternative Med 3. http:// www.colorado.edu/philosophy/vstenger/Medicine/Biofield.html.

18 Umbreit AW (2000) Healing touch: Applications in the acute care setting. AACN Clin Issues 11: 105-119.

19 Trivedi MK, Patil S, Shettigar H, Bairwa K, Jana S (2015) Effect of biofield treatment on spectral properties of paracetamol and piroxicam. Chem Sci J 6: 98.
20 Jain S, Mills PJ (2010) Biofield therapies: Helpful or full of hype? A best evidence synthesis. Int J Behav Med 17: 1-16.

21 Tabish SA (2008) Complementary and alternative healthcare: Is it evidence-based? Int J Health Sci (Qassim) 2: V-IX.

22 Barnes PM, Powell-Griner E, McFann K, Nahin RL (2004) Complementary and alternative medicine use among adults: United States, 2002. Adv Data 343: 1-19.

23 Cahil M (1998) Nurses handbook of complementary and alternative therapies. Springhouse, PA: Springhouse Corporation.

24 Aldridge D (1991) Spirituality, healing and medicine. Br J Gen Pract 41: 425-427.

25 Lenssen AW (2013) Biofield and fungicide seed treatment influences on soybean productivity, seed quality and weed community. Agricultural Journal 8: 138-143.

26 Nayak G, Altekar N (2015) Effect of biofield treatment on plant growth and adaptation. J Environ Health Sci 1: 1-9.

27 Trivedi MK, Patil S, Shettigar H, Gangwar M, Jana S (2015) In vitro evaluation of biofield treatment on cancer biomarkers involved in endometrial and prostate cancer cell lines. J Cancer Sci Ther 7: 253-257.

28 Trivedi MK, Patil S, Shettigar H, Gangwar M, Jana S (2015) An effect of biofield treatment on Multidrug-resistant Burkholderia cepacia: A multihost pathogen. J Trop Dis 3: 167.

29 Trivedi MK, Patil S, Tallapragada RMR (2015) Effect of biofield treatment on the physical and thermal characteristics of aluminium powders. Ind Eng Manage 4: 151.

30 Trivedi MK, Nayak G, Patil S, Tallapragada RM, Latiyal O (2015) Studies of the atomic and crystalline characteristics of ceramic oxide nano powders after biofield treatment. Ind Eng Manage 4: 161.

31 Pavia DL, Lampman GM, Kriz GS (2001) Introduction to spectroscopy. (3rd edn), Thomson Learning, Singapore.

32 Groza JR, Shackelford JF (2007) Materials processing handbook. Taylor and Francis group, CRC Press.

33 Inoue M, Hirasawa I (2013) The relationship between crystal morphology and XRD peak intensity on $\mathrm{CaSO}_{4} \cdot 2 \mathrm{H}_{2} \mathrm{O}$. J Cryst Growth 380: 169-175.

34 Fultz B, Howe JM (2002) In Transmission electron microscopy and diffractometry of materials. Diffraction and the X-ray powder diffractometer. (4th edn), Springer-Verlag: Berlin.

35 Raj KJA, Viswanathan B (2009) Effect of surface area, pore volume, particle size of P25 titania on the phase transformation of anatase to rutile. Indian J Chem 48A: 1378-1382.

36 Gaber A, Abdel-Rahim MA, Abdel-Latief AY, Abdel-Salam MN (2014) Influence of calcination temperature on the structure and porosity of nanocrystalline $\mathrm{SnO}_{2}$ synthesized by a conventional precipitation method. Int J Electrochem Sci 9: 81-95.

37 Sa J (2014) Fuel production with heterogeneous catalysis. CRC Press, Taylor and Francis group LLC., FL, USA.

38 Moore J (2010) Chemistry: The molecular science. (4th edn), Brooks Cole.

39 Smith BC (1999) Infrared spectral interpretation: A systematic approach. CRC Press. 